\title{
Increased migration of Lepidoptera linked to climate change
}

\author{
Tim H. SPARKS ${ }^{1}$, Roger L.H. DENNIS ${ }^{1,2}$, Philip J. CROXTON ${ }^{1}$ and MARTIN CADE $^{3}$ \\ ${ }^{1}$ NERC Centre for Ecology and Hydrology, Monks Wood, Abbots Ripton, Huntingdon, Cambridgeshire PE28 2LS, UK; \\ e-mail: ths@ceh.ac.uk \\ ${ }^{2}$ Institute for Environment, Sustainability and Regeneration, Mellor Building, Staffordshire University, College Road, Stoke on \\ Trent, ST4 2DE, UK \\ ${ }^{3}$ Portland Bird Observatory, The Old Lower Light, Portland Bill, Dorset DT5 2JT, UK
}

Key words. Lepidoptera, butterflies, moths, migration, temperature response, climate change

\begin{abstract}
The number of species of migratory Lepidoptera (moths and butterflies) reported each year at a site in the south of the UK has been rising steadily. This number is very strongly linked to rising temperatures in SW Europe. It is anticipated that further climate warming within Europe will increase the numbers of migratory Lepidoptera reaching the UK and the consequences of this invasion need urgent attention.
\end{abstract}

\section{INTRODUCTION}

Evidence is steadily accumulating on the impact of climate change on natural systems (Walther et al., 2002; Root et al., 2003). Documented changes in Lepidoptera, usually butterflies, as a consequence of rising temperatures are focussed on the northern temperate zone and include advanced phenology (Roy \& Sparks, 2000; Forister \& Shapiro, 2003; Stefanescu et al., 2003, Dell et al., 2005), changes in morphology, widening habitat base, increased population size, and altitudinal (Konvička et al., 2004; Davies et al., 2005) and geographical range shifts (Parmesan et al., 1999). These may partly compensate for population declines arising from habitat degradation and potential extinctions (Warren et al., 2001; Thomas et al., 2004; Fox et al., 2006). Little has been published to date on the consequences of climate change on the migration of insects, other than pest species (Cannon, 1998; Robinson et al., 2005). Work on historic data (up to 1962) suggested increased migration of Lepidoptera into Britain in years when temperatures in mainland Europe were higher (Sparks et al., 2005) but little research has been done on contemporary data.

In this short paper we examine incidence of, and the influence of temperature on, the migration of Lepidoptera into a site on the south coast of the UK. The migration routes and origins of these species are largely unknown but, broadly speaking, at this location the migrants will inevitably originate from southwestern Europe.

\section{MATERIAL AND METHODS}

Between 1982 and 2005, records of the incidence of Lepidoptera from both light trapping and observations during the day have been taken in the cliff-top garden (ca. 0.2 ha) at the Portland Bird Observatory, Dorset, UK $\left(50.55^{\circ} \mathrm{N}, 2.44^{\circ} \mathrm{W}\right)$ situated at the southern end of a $9 \mathrm{~km}$ headland extending into the English Channel. Recorder effort was approximately constant throughout the period. Recording takes place throughout the year except on days of exceptional wind or very low winter temperatures which experience has shown to be unproductive. Migratory status (full or partial) was determined according to Emmet \& Heath (1991) and thereby includes species that have undergone overseas flight to British shores; the term is therefore treated in the sense of Williams (1965). Since records were made in a semi-quantitative way (for example, a text description of numbers or duration), we have reduced information to binary records of presence and absence in each year for each species.

Preliminary analysis examining temperatures in the UK and continental Europe suggested greatest correlations with temperatures in SW Europe. Mean monthly temperature anomalies (differences from the 1961-1990 average) were obtained from the $5^{\circ}$ gridded CRUTEM2v dataset (www.cru.uea.ac.uk). Temperatures for SW Europe were approximated by the average of the four grid boxes $35-45^{\circ} \mathrm{N} 10-0^{\circ} \mathrm{W}$ in Spain and southern France.

Least squares regression was used to compare the total number of migratory species recorded each year with temperature anomalies. For the analysis of the presence/absence of individual species using logistic regression it is only possible to examine species with both present and absent states. Hence, only species recorded as present in between five and 19 years were compared to monthly temperature anomalies between January and September using forwards selection binary logistic regression.

\section{RESULTS}

A grand total of 75 species of migratory Lepidoptera were recorded at Portland between 1982 and 2005 (Table 1).

The annual numbers of species of migratory Lepidoptera varied between eight and 43 (mean 25) and increased significantly by an average of $1.34 \pm 0.15$ species/annum (Fig. $1, \mathrm{R}^{2}=$ $\left.79.3 \%, \mathrm{~F}_{1,22}=84.28, \mathrm{p}<0.001\right)$. Numbers of migratory species were positively related to temperature anomalies averaged over March to July and suggested a $1{ }^{\circ} \mathrm{C}$ increase in temperature was associated with an additional $14.4 \pm 2.4$ migrant species (Fig. 2, $\left.\mathrm{R}^{2}=61.9 \%, \mathrm{~F}_{1,22}=35.79, \mathrm{p}<0.001\right)$. The March to July mean temperature anomaly was also rising within this period (regression $\left.\mathrm{b}=0.058 \pm 0.012, \mathrm{R}^{2}=50.2 \%, \mathrm{~F}_{1,22}=22.22, \mathrm{p}<0.001\right)$. The predominantly positive nature of temperature anomalies shown in Fig. 2 emphasises that current temperatures are warmer than the 1961-1990 average.

There were 28 species with at least five contrasting binomial states and their stepwise binary logistic regressions are summarised in Table 2. Significant models were achieved for 22 of the 
TABLE 1. The 75 species with some migratory status as indicated by Emmet \& Heath (1991) and the number of years for which each were recorded at Portland between 1982 and 2005. Species with between five and 19 years of data were analysed individually using logistic regression.

\begin{tabular}{|c|c|c|}
\hline English name (if any) & Scientific name & Number of years recorded \\
\hline Convolvulus Hawk Moth & Agrius convolvuli & 23 \\
\hline Dark Sword-grass & Agrotis ipsilon & 23 \\
\hline Silver Y & Autographa gamma & 22 \\
\hline Hummingbird Hawk Moth & Macroglossum stellatarum & 22 \\
\hline White-speck & Mythimna unipuncta & 21 \\
\hline The Delicate & Mythimna vitellina & 21 \\
\hline Vestal & Rhodometra sacraria & 21 \\
\hline Red Admiral & Vanessa atalanta & 21 \\
\hline Painted Lady & Cynthia cardui & 20 \\
\hline Pearly Underwing & Peridroma saucia & 20 \\
\hline Clouded Yellow & Colias croceus & 19 \\
\hline White Point & Mythimna albipuncta & 19 \\
\hline Small Mottled Willow & Spodoptera exigua & 18 \\
\hline Scarce Bordered Straw & Heliothis armigera & 17 \\
\hline Bordered Straw & Heliothis peltigera & 17 \\
\hline Rush Veneer & Nomophila noctuella & 17 \\
\hline Gem & Orthonama obstipata & 16 \\
\hline Diamond-Back & Plutella xylostella & 16 \\
\hline Rusty-dot Pearl & Udea ferrugalis & 16 \\
\hline Jersey Tiger & Euplagia quadripunctaria & 15 \\
\hline Cosmopolitan & Mythimna loreyi & 15 \\
\hline European Corn Borer & Ostrinia nubilalis & 13 \\
\hline \multirow[t]{2}{*}{ Marbled-yellow Straw Pearl } & Evergestis extimalis & 12 \\
\hline & Sitochroa palealis & 11 \\
\hline $\mathrm{Ni}$ & Trichloplusia ni & 10 \\
\hline Great Dart & Agrotis crassa & 9 \\
\hline Scarce Olive-tree Pearl & Palpita unionalis & 9 \\
\hline Pine Knot-horn & Dioryctria abietella & 8 \\
\hline Striped Hawk Moth & Hyles lineata & 8 \\
\hline Isle of Wight Knot-horn & Ancylosis oblitella & 7 \\
\hline Rusty Oak & Cydia amplana & 6 \\
\hline \multirow[t]{2}{*}{ Monarch } & Danaus plexippus & 6 \\
\hline & Conobathra tumidana & 5 \\
\hline Purple Marbled & Eublemma ostrina & 5 \\
\hline Necklace Grass-veneer & Euchromius ocellea & 5 \\
\hline \multirow[t]{2}{*}{ Barred Red } & Hylaea fasciaria & 5 \\
\hline & Palpita vitrealis & 5 \\
\hline Alpine Grass-veneer & Platytes alpinella & 5 \\
\hline Hoary Footman & Eilema caniola & 4 \\
\hline Small Marbled & Eublemma parva & 4 \\
\hline Bedstraw Hawk & Hyles gallii & 4 \\
\hline Straw Dot & Rivula sericealis & 4 \\
\hline Flame Brocade & Trigonophora flammea & 4 \\
\hline Blair's Mocha & Cyclophora puppillaria & 3 \\
\hline Death's Head Hawk Moth & Acherontia atropos & 2 \\
\hline \multirow[t]{2}{*}{ Pale Shoulder } & Acontia lucida & 2 \\
\hline & Antigastra catalaunalis & 2 \\
\hline Porter's Rustic & Athetis hospes & 2 \\
\hline Red-headed Chestnut & Conistra erythrocephala & 2 \\
\hline \multirow[t]{2}{*}{ Many-lined } & Costaconvexa polygrammata & 2 \\
\hline & Diasemiopsis ramburialis & 2 \\
\hline The Passenger & Dysgonia algira & 2 \\
\hline \multirow[t]{2}{*}{ Pygmy Footman } & Eilema pygmaeola & 2 \\
\hline & Ethmia bipunctella & 2 \\
\hline
\end{tabular}


TABLE 1 (continued). The 75 species with some migratory status as indicated by Emmet \& Heath (1991) and the number of years for which each were recorded at Portland between 1982 and 2005. Species with between five and 19 years of data were analysed individually using logistic regression.

\begin{tabular}{lcc}
\hline English name (if any) & Scientific name & Number of years recorded \\
\hline Old World Webworm & Hellula undalis & 2 \\
Bloxworth Snout & Hyphena obsitalis & 2 \\
Four-spotted Footman & Lithosia quadra & 2 \\
Tawny Wave & Scopula rubiginata & 2 \\
Small Thistle Moth & Tebenna micalis & 1 \\
Rosy Underwing & Catocala electa & 1 \\
Golden Twin-spot & Chrysodeixis chalcites & 1 \\
& Crombrugghia laetus & 1 \\
The Nutmeg & Discestra trifolii & 1 \\
Angle-striped Sallow & Enargia paleacea & 1 \\
Long Tailed Blue & Lampides boeticus & 1 \\
Gypsy Moth & Lymantria dispar & 1 \\
Dewick's Plusia & Macdunnoughia confusa & 1 \\
Radford's Flame Shoulder & Ochropacha leucogaster & 1 \\
Clancy's Rustic & Platyperigea kadenii & 1 \\
Powdered Pearl & Psammotis pulveralis & 1 \\
Dark Mottled Willow & Spodoptera cilium & 1 \\
Cypress Carpet & Thera cupressata & 1 \\
Orache Moth & Trachea atriplicis & 1 \\
Yellow-underwinged Pearl & Uresphita polygonalis & 1 \\
Crimson Speckled & Utetheisa pulchella & 1 \\
\hline
\end{tabular}

28 species. Of the 39 terms included in all models only four had negative coefficients, indicating that higher temperatures in SW Europe were generally associated with greater incidence of migratory Lepidoptera in the southern UK.

\section{DISCUSSION}

The majority of migratory Lepidoptera to the south coast of England originate from the south and will have to fly over a minimum of $150 \mathrm{~km}$ of open sea to reach the recording site. Migration of insects into Britain, as between all land areas, is a persistent feature. It is considered to be the outcome of reproductive bet-hedging - spreading breeding effort in space and time over a range of environmental conditions (Loxdale \& Lushai, 1999; Holland et al., 2006, but see Dennis, 1993); the

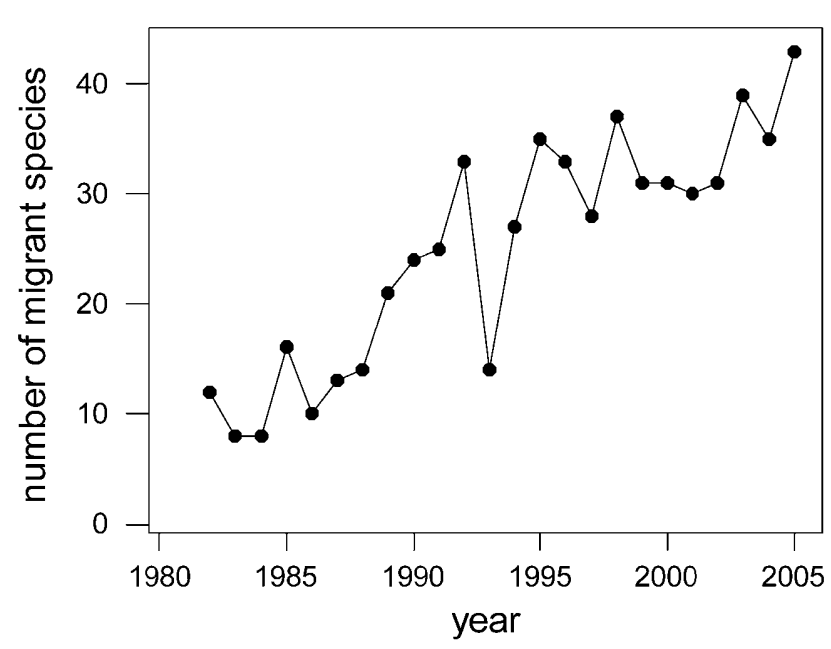

Fig. 1. The number of migrant Lepidoptera species recorded each year at the Portland Bird Observatory, UK. form (altitude, distance, direction) that migration takes is closely related to atmospheric conditions (Wood et al., 2006). The relationships we calculate above suggest an increase of 14 species for each $1^{\circ} \mathrm{C}$ increase in temperatures in SW Europe. Thus, a relatively modest degree of warming could make a substantial difference to the number of migratory Lepidoptera reaching new territories, furthermore numbers could well be higher on continental land masses where no physical barriers exist (e.g. Konvička et al., 2004).

The UK has a sparse arthropod fauna relative to its land area, thought to be a consequence of its island status and geological history (Dennis, 1993). Even so, some 89 moth species alone

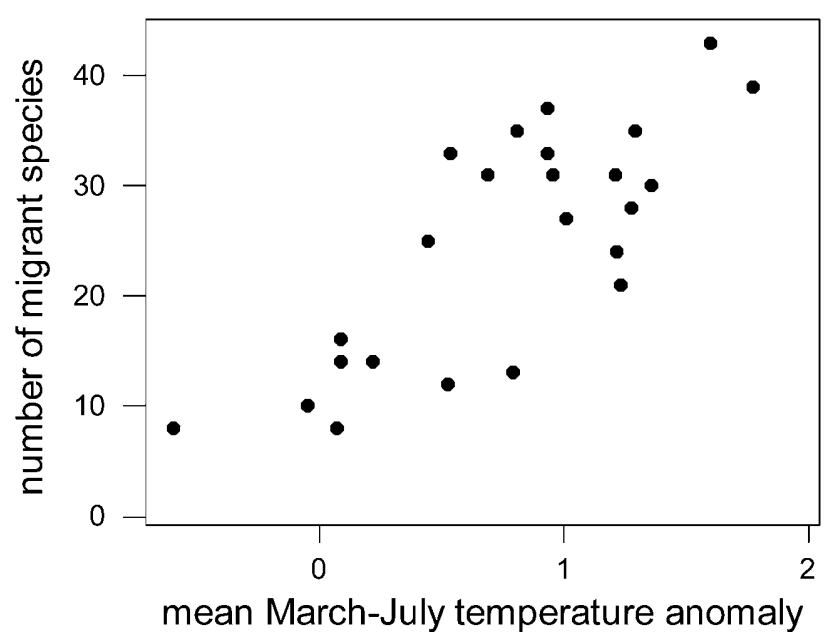

Fig. 2. The relationship between the number of migrant Lepidoptera species recorded each year at the Portland Bird Observatory, UK and mean March-July temperature anomalies in SW Europe, see text for details. 
TABLE 2. Stepwise logistic regression on nine monthly mean temperatures (January-September) for the 28 species which had at least 5 years in an opposite state (present or absent). Months are indicated by numerals $(1=$ January etc.) and are displayed in the order of entry. All coefficients were positive except where indicated by "( $(-)$ ". The deviance $(\mathrm{G})$ and the overall model significance $(\mathrm{P})$ are also shown.

\begin{tabular}{|c|c|c|c|c|}
\hline Species & $\mathrm{n}$ & $\begin{array}{l}\text { Months included } \\
\text { in model }\end{array}$ & $\mathrm{G}$ & $\mathrm{P}$ \\
\hline Colias croceus & 19 & 7,4 & 15.70 & $<0.001$ \\
\hline Mythimna albipuncta & 19 & 5 & 10.41 & 0.001 \\
\hline Spodoptera exigua & 18 & None & & \\
\hline Heliothis armigera & 17 & 5,1 & 11.40 & 0.003 \\
\hline Heliothis peltigera & 17 & 5 & 5.80 & 0.016 \\
\hline Nomophila noctuella & 17 & 7,2 & 23.84 & $<0.001$ \\
\hline Orthonama obstipata & 16 & 5 & 4.28 & 0.039 \\
\hline Plutella xylostella & 16 & $8,9(-)$ & 11.42 & 0.003 \\
\hline Udea ferrugalis & 16 & $5,6,3,7$ & 25.39 & $<0.001$ \\
\hline Euplagia quadripunctaria & 15 & None & & \\
\hline Mythimna loreyi & 15 & None & & \\
\hline Ostrinia nubilalis & 13 & 5 & 9.36 & 0.002 \\
\hline Evergestis extimalis & 12 & 5 & 5.51 & 0.019 \\
\hline Sitochroa palealis & 11 & $3,4,6$ & 27.83 & $<0.001$ \\
\hline Trichloplusia ni & 10 & $9(-), 6$ & 9.34 & 0.009 \\
\hline Agrotis crassa & 9 & 7 & 4.52 & 0.033 \\
\hline Palpita unionalis & 9 & 5,2 & 14.65 & 0.001 \\
\hline Dioryctria abietella & 8 & $3,2(-)$ & 14.68 & 0.001 \\
\hline Hyles lineata & 8 & None & & \\
\hline Ancylosis oblitella & 7 & $4,7,1$ & 18.18 & $<0.001$ \\
\hline Cydia amplana & 6 & 6 & 15.66 & $<0.001$ \\
\hline Danaus plexippus & 6 & 4 & 4.78 & 0.029 \\
\hline Conobathra tumidana & 5 & 6,3 & 17.95 & $<0.001$ \\
\hline Eublemma ostrina & 5 & 8 & 6.83 & 0.009 \\
\hline Euchromius ocellea & 5 & None & & \\
\hline Hylaea fasciaria & 5 & None & & \\
\hline Palpita vitrealis & 5 & 6 & 13.84 & $<0.001$ \\
\hline Platytes alpinella & 5 & $4,5,9(-)$ & 18.06 & $<0.001$ \\
\hline
\end{tabular}

are known to have colonised Britain during the last century (Fox et al., 2006), undoubtedly indicating a northwards shift in distributions (e.g. Skelton, 1999). Some noteworthy new insects have arrived in recent years [e.g. Nezara viridula (L.), Hemiptera] (Shardlow \& Taylor, 2004; Hill et al., 2005) and are now expanding their ranges northwards (e.g. Dolichovespula media Retzius, Hymenoptera) (Hammond et al., 1989; Edwards, 1997). Insect migration is a topic of great importance to continental countries as well as islands (Drake \& Gatehouse, 1995); it has implications for human health and agrarian economics as well as for conservation. Migrating insects introduce species hosting infections and disease (e.g. malarial mosquitoes, Chin \& Welsby, 2004; calyptrate flies, Goulson et al., 2005) to new regions. They can also have a serious impact on essential crops (e.g. aphids, Gilbert et al., 2005; Smith et al., 2005) and garden plants [e.g. Lilioceris lilii (Scopoli) (Chrysomelidae), Salisbury, 2003] and influence control measures with repercussions for resident species (Gullan \& Cranston, 2005). From a direct conservation viewpoint, migrating species potentially impact on resident species, on their resources, but can also include species of conservation concern over wider regions (e.g. Sphingidae, Pittaway, 1993). The threat imposed by migratory species relates not just to their mobility but to their adaptability which is believed to be closely linked to their mobility; migratory species may be among the most adaptable of species (Cannon, 1998). For this reason, they may represent a competitive threat to resident species which typically have lower mobility and are more specialised in habitat requirements.

The possible consequences of a climate induced change in burgeoning migrant insects, with potentially serious consequences for health, agriculture and conservation of resident taxa, requires immediate attention.

\section{REFERENCES}

CANNON R.J.C. 1998: The implications of predicted climate change for insect pests in the UK, with emphasis on nonindigenous species. Global Change Biol. 4: 785-796.

Chin T. \& Welsby P.D. 2004: Malaria in the UK: past, present, and future. Postgrad. Med. J. 80: 663-666.

Davies Z.G., Wilson R.J., Brereton T.M. \& Thomas C.D. 2005: The re-expansion and improving status of the silver-spotted skipper butterfly (Hesperia comma) in Britain: a metapopulation success story. Biol. Conserv. 124: 189-198.

Dell D., Sparks T.H. \& Dennis R.L.H. 2005: Climate change and the effect of increasing spring temperatures on emergence dates of the butterfly Apatura iris (Lepidoptera: Nymphalidae). Eur. J. Entomol. 102: 161-167.

DenNIS R.L.H. 1993: Butterflies and Climate Change. Manchester University Press, Manchester, 302 pp.

Drake V.A. \& Gatehouse A.G. 1995: Insect Migration. Tracking Resources through Space and Time. Cambridge University Press, Cambridge, 496 pp.

Edwards R. (ed.) 1997: Provisional Atlas of the Aculeate Hymenoptera of Britain and Ireland. Part 1. Biological Records Centre, Huntingdon, 139 pp.

Emmet A.M. \& Heath J. (eds) 1991: The Moths and Butterflies of Great Britain and Ireland. Vol. 7, Part 2. Harley Books, Colchester, $400 \mathrm{pp}$.

Forister M.L. \& Shapiro A.M. 2003: Climatic trends and advancing spring flight of butterflies in lowland California. Global Change Biol. 9: 1130-1135.

Fox R., Conrad K.F., Parsons M.S., Warren M.S. \& Woiwod I.P. 2006: The State of Britain's Larger Moths. Butterfly Conservation, East Lulworth, 112 pp.

Gilbert M., Guichard S., Freise J., Gregoire J.C., Heitland W., Straw N., Tilbury C. \& Augustin S. 2005: Forecasting Cameraria ohridella invasion dynamics in recently invaded countries: from validation to prediction. J. Appl. Ecol. 42: 805-813.

Goulson D., Derwent L.C., Hanley M.E., Dunn D.W \& AboLINS S.R. 2005: Predicting calyptrate fly populations from the weather, and probably consequences of climate change. $J$. Appl. Ecol. 42: 795-804.

Gullan P.J. \& Cranston P.S. 2005: The Insects. An Outline of Entomology. Blackwell Publishing, Oxford, 505 pp.

Hammond P.M., Sмith K.G.V., Else G.R. \& Allen G.W. 1989: Some recent additions to the British insect fauna. Entomol. Mon. Mag. 125: 95-102.

Hill M., Baker R., Broad G., Chandler P.J., Copp G.H., Ellis J., Jones D., Hoyland C., Laing I., Longshaw M., Moor N., Parrott D., Pearman D., Preston C., Smith R. \& Waters R. 2005: Audit of Non-native Species in England. English Nature Research Report No. 662. English Nature, Peterborough, 81 $\mathrm{pp}$ 
Holland R.A., Wikelski M. \& Wilcove D.S. 2006: How and why do insects migrate. Science 313: 794-796.

KonvičKa M., Maradová M., Beneš J., Fric Z. \& KepKa P. 2004: Uphill shifts in distribution of butterflies in the Czech Republic: effects of changing climate detected on a regional scale. Global Ecol. Biogeog. 12: 403-410.

LoXdALE H.D. \& LushaI G. 1999: Slaves to the environment: the movement of herbivorous insects in relation to their ecology and genotype. Phil. Trans. R. Soc. Lond. (B) 354: 1479-1495.

Parmesan C., Ryrholm N., Stefanescu C., Hill J.K., Thomas C.D., Descimon H., Huntley B., Kaila L., Kullberg J., Tammaru T., Tennen J., Thomas J.A. \& Warren M. 1999: Poleward shift of butterfly species' ranges associated with regional warming. Nature 399: 579-583.

PitTaway A.R. 1993: The Hawkmoths of the Western Palaearctic. Harley Books, Colchester, 240 pp.

Robinson R.A., Learmonth J.A., Hutson A.M., Macleod C.D., Sparks T.H., Leech D.I., Pierce G.J., Rehfisch M.M. \& Crick H.Q.P. 2005: Climate Change and Migratory Species. Department for Environment, Food and Rural Affairs, London, 304 pp.

Root T.L., Price J.T., Hall K.R., Schneider S.H., Rosenzweig C. \& Pounds J.A. 2003: Fingerprints of global warming on wild animals and plants. Nature 421: 57-60.

Roy D.B. \& Sparks T.H. 2000: Phenology of British butterflies and climate change. Global Change Biol. 6: 407-416.

SAlisbury A. 2003: A further note on the continued spread in Britain of the lily beetle Lilioceris lilii (Scopoli) (Chrysomelidae) with notes on its host plant range. The Coleopterist 12: $67-75$.

Shardlow M.E.A. \& TAYlor R. 2004: Is the Southern Green Shield Bug, Nezara viridula (L.) (Hemiptera: Pentatomidae) another species colonising Britain due to climate change? Br. J. Entom. Nat. Hist. 17: 143-146.

Skelton M. 1999: Successful overwintering by Clouded Yellow Colias croceus in southern England. Atropos 8: 3-6.
Smith R.M., Baker R.H.A., Malumphy C.P., Hockland S., Hammon R.P., OstojÁ-Starzewski J.C. \& Collins D.W. 2005: Non-native invertebrate plant pests established in Great Britain: an assessment of patterns and trends. BCPC Symposium Proc. 81: 119-124.

Sparks T.H., Roy D.B. \& Dennis R.L.H. 2005: The influence of temperature on migration of Lepidoptera into Britain. Global Change Biol. 11: 507-514.

Stefanescu C., Peñuelas J. \& Filella I. 2003: Effects of climatic change on the phenology of butterflies in the northwest Mediterranean Basin. Global Change Biol. 9: 1494-1506.

Thomas C.D., Cameron A., Greene R.E., Bakkenes M., Beaumont L.J., Collingham Y.C., Erasmus B.F.N., De Siqueira M.F., Grainger A., Hannah L., Hughes L., Huntley B., Van JaArsveld A.S., Midgley G.F., Miles L., Ortega-Huerta M.A., Peterson A.T., Phillips O.L. \& Williams S.E. 2004: Extinction risk from climate change. Nature 427: 145-148.

Walther G.-R., Post E., Convey P., Menzel A., Parmesan C., Beebee T.J.C., Fromentin J.M., Hoegh-Guldberg O. \& BairLEIN F. 2002: Ecological responses to recent climate change. Nature 416: 389-395.

Warren M.S., Hill J.K., Thomas J.A., Asher J., Fox R., Huntley B., Roy D.B., Telfer M.G., Jeffcoate S., Harding P., Jeffcoate G., Willis S.G., Greatorex-Davies J.N., Moss D. \& Thоmas C.D. 2001: Rapid responses of British butterflies to opposing forces of climate and habitat change. Nature 414: 65-69.

Williams C.B. 1965: Insect Migration. Collins, London, 237 pp. Wood C.R., Chapman J.W., Reynolds D.R., Barlow J.F., Smith A.D. \& WorwOD I.P. 2006: The influence of the atmospheric boundary layer on nocturnal layers of noctuids and other moths migrating over southern Britain. Int. J. Biometeor. 50: 193-204.

Received September 13, 2006; revised and accepted October 19, 2006 